\title{
Refinancing and Decentralization: Evidence from China*
}

\author{
Albert Park and Minggao Shen
}

This version: June 2006

First draft: March 2001

\begin{abstract}
Decentralization can complement market liberalization by strengthening incentives of agents to exploit local information in response to market signals. In China, however, banks centralized lending authority following financial reforms in the mid-1990s. We offer a new theory of financial decentralization in which centralization provides a credible commitment not to refinance bad projects by reducing available information. Using data from Chinese rural financial institutions, we empirically assess the determinants of decentralization and the likelihood of collateral seizure, strongly confirming the predictions of the refinancing model. We conclude that the inability of financial systems to exploit local information in weak institutional environments may limit the efficiency of financial intermediation despite financial market liberalization.

JEL Codes: G2, D8, P3

Keywords: banking, decentralization, refinancing, transition, China

* Correspondence: Albert Park, Department of Economics, University of Michigan, Ann Arbor, MI 48109-1220, U.S.A., email: alpark@umich.edu. An earlier draft of this paper was titled, "Decentralization in Financial Institutions: Theory and Evidence from China."

Albert Park is associate professor of economics, University of Michigan and Minggao Shen is associate professor, China Center for Economic Research, Peking University. We thank the Ford Foundation and the William Davidson Institute for supporting the field research, and Masahiko Aoki, John Bonin, Loren Brandt, Andrew Coleman, Lawrence Lau, David Li, Guo Li, Hongbin Li, Ronald McKinnon, Anna Meyendorff, Jean Oi, Scott Rozelle, Rohini Somanathan, Jan Svejnar, and Colin Lixin Xu for helpful comments.
\end{abstract}




\section{Refinancing and Decentralization: Empirical Evidence from China}

\section{Introduction}

In recent years, financial liberalization has been a main focus of reform in developing countries and more recently in transition economies (e.g., Haggard and Lee, 1995). Financial liberalization transforms a heavily regulated system into a market-oriented one by reducing barriers to entry, reducing government influence over credit allocation, and increasing reliance on market-determined interest rates. Conventional wisdom holds that decentralization of control rights goes hand-in-hand with market liberalization. With greater decision-making authority, local managers may have greater incentives to exploit local information in response to market signals, which increases the efficiency of resource allocation. Effective use of local information may be especially important when there are large information asymmetries between central and local managers. In banking, this is likely to occur in weak institutional environments in which credit ratings, high quality appraisal and auditing services, standardized reporting systems, and well-developed legal systems are absent.

Surprisingly, in China most banks responded to financial reforms in the mid-1990s by centralizing rather than decentralizing control rights. The reforms intended to further the commercialization of state-owned banks and improve the responsiveness of lending to economic fundamentals, but did not liberalize interest rates. ${ }^{1}$ This contrasts with the history of key reforms in China's agricultural and industrial sectors that decentralized decisionmaking authority to households and firm managers and liberalized prices (Naughton, 1995). But it is consistent with evidence from developing and transition economies that financial liberalization and decentralization may have unintended effects if underlying institutional factors are left unaddressed (Cho, 1986; Buch, 1996; Koford and Tschoegl, 1997; Schmidt, 1998). ${ }^{2}$

This paper provides a new theory of financial decentralization that explains why decentralization may not always be desirable, especially in developing and transition

\footnotetext{
1 See Park and Sehrt (2001) for a detailed description of financial reforms in the mid-1990s.

${ }^{2}$ Cho (1986) shows that poorly developed capital markets and the preponderance of bank loans in corporate financing may have prevented financial liberalization from having its intended effects. Based on the experiences of Eastern European countries, Buch (1996) argues that successful domestic financial liberation and banking reform requires the creation of a market-based incentive system and a new institutional framework (e.g., mechanisms of corporate control for both banks and enterprises) to facilitate banks hardening the budget constraints of enterprises and coping with the asymmetric information problem in financial markets.
} 
economies. The model's key insight is that by improving local information, decentralization can reduce the ability of lenders to credibly commit not to refinance bad projects, the effect of which is to soften the budget constraint of borrowers. In the context of a corporation, Cremer (1995) shows that more information may hurt the principal's ability to refuse renegotiation. Berglof and Roland (1998) find that when liquidation costs are sufficiently high, lenders may lack the credibility to liquidate financially distressed projects, leading to soft budget constraints. In this paper, we present a model in which centralization can provide a credible commitment not to refinance bad projects, which improves project performance and loan repayment by increasing the effort incentives of firm managers. In China, financial centralization increased as concerns about refinancing grew in the mid-1990s when the economy slowed and increasing numbers of firms encountered financial difficulties.

Our argument uses the key insight from Dewatripont and Maskin (1995) to come to an exactly opposite conclusion. They argue that decentralization in the form of a division of large banks into small ones can serve as a commitment device that helps lenders harden the budget constraint of borrowers. This is because, unlike large banks, small banks are incapable of refinancing ongoing projects independently. However, other potential lenders may be unwilling to refinance projects when they have poor information about firm quality. Entrepreneurs with questionable projects will anticipate that refinancing is less likely and will not seek financing in the first place, or will exert greater effort to make projects successful once the project is financed. In both our model and that of Dewatripont and Maskin, credible commitment not to refinance is achieved by taking lending authority out of the hands of bank managers who have better information. However, in our case this is accomplished by centralizing lending authority rather than dividing large banks into small banks, which Dewatripont and Maskin describe as "decentralization."

The refinancing problem is likely to be particularly important in transition economies because poorly developed institutions make liquidation of collateral costly, so that borrowers are more likely to anticipate refinancing loans if projects go bad. In China, "fishing" projects are very common in which outstanding debt serves as bait for attracting additional loans because banks cannot get the old loans back unless they are willing to make more new loans (Li and Li, 1996). This dynamic may help explain the growth in debt-asset ratios in both state-owned enterprises and rural collective enterprises in the 1990s (Lardy, 1998; Park and 
Shen, 2003). Lack of accounting standards often observed in transition economies may exacerbate the problem (Buch, 1996). For example, if banks are able to roll over loans to hide repayment problems, then liquidation of projects may lead directly to large accounting losses which may be viewed as unacceptable to bank managers. This makes refinancing more attractive, undermining the credibility of threats to liquidate projects once defaults occur.

In this paper, we use bank-level data on managerial decision-making authority in a large transition economy to test whether theory can explain observed heterogeneity in decentralization of lending authority in financial institutions. The unique data set was collected in surveys of rural financial institutions, enterprises, and local government officials conducted by the authors in 1998 in southern China. Surprisingly, we found no existing empirical research on the validity of different theories explaining financial decentralization. The question is important for validating the assumptions of existing theory, and practically for assessing the efficiency of financial resource allocation.

The ongoing financial transition in China offers an excellent setting for empirical study of financial decentralization. China is an interesting case because banks recently became commercialized but supporting institutions are not fully developed, leading to rich variation across space in the extent of decentralization. Financial reform in China aims at transforming financial institutions from government-run banks to independent financial intermediaries (Qian, 1994; and Lardy, 1998). Important aspects of China's financial reform in the mid-1990s were the introduction of bank competition among state-owned banks, the strengthening of profit incentives for managers, and the transfer of policy loans to newly established policy banks (Park and Sehrt, 2001). Individual banks have been allowed to decide for themselves whether or not to decentralize lending authority to local bank managers.

In China and elsewhere, agency problems provide an alternative explanation for centralized decision-making. Local bank managers may collude with or be influenced by local government leaders, who, as social planners of local communities, internalize not only the economic benefits of running firms but also non-economic ones such as enterprise and employment creation, and potential tax extraction (Svejnar, 1990; Jin and Qian, 1998). They may also take payoffs from firms. During the period of study, many rural firms were owned 
by local governments, making the corrupt influence of firms and local governments often indistinguishable.

Policy lending and soft budget constraints are a notorious problem plaguing financial institutions in transition economies (Kornai, 1986). However, we study decision-making in banks at the lowest administrative level in China, the township, where such problems are considered to be less serious (Qian and Roland, 1998). In China, financial reforms strengthened managerial profit incentives, and our survey found that policy influence on lending fell substantially during the mid-1990s. The timing of centralization thus is not consistent with the expected reduction in moral hazard problems over time (Park and Shen, 2003). ${ }^{3}$

The problem we focus upon in this paper is the allocation of lending authority between central managers, or upper level management (the county bank branch in the empirical section), and local managers, or lower level management (the township branch). In section 2, we present two models, a costly information model and a refinancing model, to illustrate how different factors affect optimal decentralization in a two-tier hierarchy. This yields a set of theoretical predictions on the effect of key parameters on the decentralization decision. Section 3 presents the evidence from China. We first introduce the data, then describe financial decentralization and commercialization in China's rural financial sector, discuss the estimation strategy, and present the results of our empirical analysis of the determinants of decentralization and the propensity for bank managers to seize collateral. Section 4 concludes.

Our main findings are that the desire to credibly commit against refinancing theoretically can explain centralization, and that this explanation is strongly supported by the Chinese data. We conclude that in imperfect institutional environments, centralization can help resolve agency and commitment problems, although likely at substantial cost in terms of lost information and reduced incentives of local managers. This outcome suggests that rapid commercialization of banking systems in transition economies will not automatically lead to substantial improvement in financial intermediation unless deeper institutional reforms occur as well.

\footnotetext{
${ }^{3}$ Centralization might also enable banks to better diversify their portfolios regionally, but interviews found this motivation not to be important empirically.
} 


\section{Theory}

We present two complementary models of decentralization. The first, which we call the costly information model, is a one-period model that illustrates how the decision to decentralize is affected by the benefits and costs of using local information. Simple extensions examine how collateral, financial competition, and agency problems (i.e., local government influence over lending) affect optimal decentralization. We then present a model with multiple periods to examine how the refinancing problem alters key predictions about the model parameters. Both models assume that central managers are profit maximizers.

Together, the two models are meant to capture all of the factors most likely to influence the decentralization decision in the Chinese context. First, the costliness of local information is an important consideration in environments when information systems and institutions are underdeveloped, as in China. Second, with underdeveloped legal institutions and the lack of an effective bankruptcy law, variation in the ability to seize collateral is likelty to influence the center's willingness to delegate lending authority. Third, the agency explanation (influence of government or firms on bank lending decisions) has been an oftcited problem in China and other transition economies, where soft budget constraints are viewed as pervasive. Fourth, because of continued state domination of the banking system, differences in financial competition may also influence lending. Finally, as motivated in the introduction, given the problems of poor information and the increasing number of failed projects in the mid-1990s, the refinancing problem is particularly salient in China.

\subsection{The Costly Information Model}

We consider a local economy with $N$ firms whose types are uniformly distributed. A firm's type $\theta \in\left[\theta_{0}, 1\right]$ is the probability of project success, where $\theta_{0}$ is the least profitable firm type in the economy. We assume that all firms demand loans and that firms are only able to repay loans when their projects are successful. Therefore, $\theta$ is also the expected rate of repayment. For simplicity, we assume that all firms require one dollar of investment to operate.

Each bank has two levels, the center and the local branch, or local. The center controls all of the resources of the bank and decides whether to delegate control rights over 
lending to the local manager. Following Aghion and Tirole (1997) and Strausz (1997), the center and local managers are endowed with different technologies in gathering information about firm types. With a fixed cost of $m$, the local manager can perfectly identify $\theta$ for each firm in the local economy. ${ }^{4}$ The central manager, who does not have access to the local information technology, knows only the distribution of firm types, which is common knowledge. Information about firm type is valuable because not all firms are profitable to finance, i.e., $\theta_{0} R_{L}-R_{I}<0$, where $R_{I}=1+r_{I}$ and $R_{L}=1+r_{L}$. Here, $r_{I}$ and $r_{L}$ are the market intermediation rate, or cost of funds, and the lending interest rate, respectively. Interest rates are assumed to be exogenous to both central and local managers, which is a reasonable assumption in China's regulatory environment. ${ }^{5}$

Without loss of generality, we assume that both central and local managers are risk neutral. Assuming he is willing to invest $m$ for project screening, a local manager who is maximizing profits will lend to all firms for which $\theta R_{L} \geq R_{I}$. This acts as an incentive compatibility constraint for the center. The threshold borrowing type below which no lending occurs is

$$
\theta_{P}=\frac{R_{I}}{R_{L}}
$$

and $\theta_{0} \leq \theta_{P} \leq 1$. The local bank manager's participation constraint is

$$
N\left(\frac{1-\theta_{P}}{1-\theta_{0}}\right)\left[\left(\frac{1+\theta_{P}}{2}\right) R_{L}-R_{I}\right]-W-m \geq 0
$$

The first term of equation (2) is the net expected profits from lending and $N_{P}=N\left(\frac{1-\theta_{P}}{1-\theta_{0}}\right)$ is the optimal number of firms financed by local managers, where $N$ is the total number of potential borrowers in the local economy. $W$ is the transfer from the local to the center, which we assume is a lump sum. It is easy to show that a profit-sharing contract is nondistorting and equivalent to a lump sum payment. Contracts that do distort incentives, such as revenue-sharing contracts, are dominated by lump sum transfers which can achieve full

\footnotetext{
${ }^{4}$ The assumption that screening exhibits scale economies appears often in the literature, e.g., Berglof and Roland (1998).

${ }^{5}$ Interest rates are strictly regulated in China. The exogeneity assumption is discussed in detail in section 3.3.
} 
efficiency and full rent extraction. ${ }^{6}$ To simplify, we also assume the local manager has zero reservation utility.

If the center does not decentralize lending authority, she will lend to all firms that apply for loans as long as the expected profit of lending plus any private benefits to the center from maintaining lending authority (p) is positive, or $\left(\frac{1+\theta_{0}}{2}\right) R_{L}-R_{I}+p \geq 0$; otherwise, no firms will be financed. If $p>0$, the center will prefer centralization when the central and local managers are equally uninformed about borrower types, which occurs if the local manager is unwilling to invest in $\mathrm{m}$. In this case, profits from central and local lending would be the same, but the center would lose private benefits $\mathrm{p}$ under decentralization.

The central manager is willing to decentralize control rights over lending if the benefits from delegation exceed the expected profits from centralized lending. A necessary and sufficient condition for decentralization is the following:

$$
W \geq N\left[\left(\frac{1+\theta_{0}}{2}\right) R_{L}-R_{I}+p\right]
$$

The center sets $W$ to maximize the extraction of surplus from the local manager.

From (1), (2) and (3), it follows that the center will decentralize control over lending if and only if

$$
N\left(R_{I}-\theta_{0} R_{L}\right)^{2}-2\left(1-\theta_{0}\right)(m+N p) R_{L} \geq 0 .
$$

Deriving comparative statics from (4) is straightforward and yields the following proposition.

PROPOSITION 1. In the costly information model with fixed information costs, the center is more likely to decentralize control over lending if the information cost $(m)$ and lending interest rate $\left(R_{L}\right)$ are lower and if the cost of funds $\left(R_{I}\right)$ and number of firms $(\mathrm{N})$ are higher. The effect of the overall quality of firms $\left(\theta_{0}\right)$ is ambiguous. ${ }^{7}$

Proof. Immediately follows from the derivatives of (4).

\footnotetext{
${ }^{6}$ This presumes the absence of agency problems, in which case performance-linked contracts may be preferred. ${ }^{7}$ If $m$ is a variable cost, i.e., $N\left(\frac{1-\theta_{P}}{1-\theta_{0}}\right)\left[\left(\frac{1+\theta_{P}}{2}\right) R_{L}-R_{I}\right]-W-N\left(\frac{1-\theta_{P}}{1-\theta_{0}}\right) m \geq 0$, we can rewrite equation (4) as $\left(R_{I}-\theta_{0} R_{L}\right)^{2}-2(m+p)\left(R_{I}-R_{L}\right)-2\left(1-\theta_{0}\right) P R_{L} \geq 0$. This leads to one change: the number of firms $(N)$ has no impact on decentralization.
} 
Proposition 1 states that the center may decentralize lending authority to take advantage of the local manager's costly access to better information. The gain from decentralization can be enlarged if local managers gather information on borrowers more effectively, i.e., more cheaply. A higher lending interest rate leads banks to lend to lower quality firm types under decentralization, reducing the expected increase in repayment rates from decentralization. Also, since there is more lending in centralized systems (all firms get loans), a higher interest rate increases the absolute profit level under centralization compared to under decentralization. For these two reasons, a higher lending interest rate reduces the likelihood of decentralization. By a similar logic, the cost of funds has the opposite effects of the lending interest rate. When we assume scale economies in information gathering, a greater number of potential borrowing firms $(N)$ can lower the per-loan cost of information. Finally, higher firm quality (higher $\theta_{0}$ ) has an ambiguous effect on decentralization. A higher $\theta_{0}$ raises total profitability under both decentralization and centralization but reduces the benefits of better screening under decentralization since a greater share of all firms are financed. In an extreme case, when $\theta_{0}$ reaches a level where all firms applying for loans are financed by the local manager, the center may in fact suffer a loss of the amount $m$ if she decentralizes lending authority.

We next extend the model to examine the roles of collateral, financial competition, and government influence over lending.

Collateral. The use of collateral increases the payoff to the lender when a project fails. With collateral V, we can rewrite equations (2) and (3) as follows.

$$
\begin{gathered}
N\left(\frac{1-\theta_{P}}{1-\theta_{0}}\right)\left\{\left[\left(\frac{1+\theta_{V}}{2}\right) R_{L}+\left(\frac{1-\theta_{V}}{2}\right) V\right]-R_{I}\right\}-W-m \geq 0 \\
W \geq N\left\{\left[\left(\frac{1+\theta_{0}}{2}\right) R_{L}+\left(\frac{1-\theta_{0}}{2}\right) V+p\right]-R_{I}\right\}
\end{gathered}
$$

where $\theta_{V}=\frac{R_{I}-V}{R_{L}-V}$. Accordingly, we derive a new version of equation (4),

$$
N\left[\left(R_{I}-V\right)-\theta_{0}\left(R_{L}-V\right)\right]^{2}-2(m+N p)\left(1-\theta_{0}\right)\left(R_{L}-V\right) \geq 0 .
$$


Comparing (4a) to (4) reveals that collateral acts like an equal shift in both the lending interest rate and the cost of funds. Effective collateral lowers the effective cost of funds and increases the expected return to lending--price effects. However, because $\theta_{V} \leq \theta_{P}$, the use of collateral increases the amount of projects to be financed by both the center and local, which reduces the expected benefits of better screening--a portfolio effect. Overall, the impact of collateral on optimal decentralization is ambiguous.

Bank Competition. The introduction of bank competition may affect both the number of potential borrowers and the distribution of firm types available to the local branch. We define $N_{P}$ as the optimal number of firms that are financed by the local manager, where $N_{P}=N\left(\frac{1-\theta_{P}}{1-\theta_{0}}\right)$. If we assume that competitors are endowed with identical screening technology, the distribution of firm types available to each bank is the same. However, competition will reduce $N$, the total number of potential borrowing firms available to each bank. This raises the information cost per loan, making centralization of lending authority more likely. If screening technologies of competitors differ, competition may also affect the distribution of firm types in the pool of potential borrowers. The result on competition also disappears if information costs are assumed to be variable rather than fixed.

Government Influence and Corruption. Extending the costly information model, we assume that local government leaders can impose a lump sum fine, $G$, should their demand for new loans for any firms in their jurisdiction be unsatisfied. To avoid the penalty, local managers will finance projects for which $R_{L} \theta-R_{I}+G \geq 0$. This formalization also accommodates positive payments if the loan is made, and so can be considered a general model of corruption. During the period of study, most firms were owned by local governments, so local government influence and bribery by firms were often difficult to distinguish.

With this setup, the threshold firm type receiving loans when there is government influence on lending is $\theta_{G}$, where $\theta_{G}=\left(R_{I}-G\right) / R_{L} \leq \theta_{P}$. The difference $\theta_{P}-\theta_{G}$ represents the degree of influence of government officials on lending decisions. Re-deriving the local manager's participation constraint and substituting into (3) gives us the following condition for decentralization: 


$$
N\left(\theta_{0}^{2}-\theta_{G}^{2}\right) R_{L}-2 N\left(\theta_{0}-\theta_{G}\right) R_{I}-2\left(1-\theta_{0}\right)(m+N p) \geq 0
$$

By examining the derivative of (4b), it is straightforward to show that the more aggressive the local government (high $G$ or, equivalently, low $\theta_{G}$ ), the less likely decentralization will occur. There could be scope for designing incentive contracts to address the agency problem without centralizing decision-making, but that takes us beyond the scope of this paper.

\subsection{The Refinancing Model}

To examine the refinancing decision, we extend the costly information model to multiple periods and exclude parameters, such as the cost of information, whose effects do not differ from the costly information model. As noted earlier, our model shares an essential feature of that of Dewatripont and Maskin (1995); it argues that the lack of information can allow the lender to credibly commit not to refinance. However, our definition of decentralization is different. We are interested in whether the center decentralizes control rights to allow local managers to approve loans, or reserves such approval rights for herself. We show that, by centralizing loan refinancing decisions, the center can credibly commit to having poorer information and to not refinance projects, leading in some circumstances to greater effort by borrowers to make projects successful.

In the game between creditor and borrower, we assume that the bank makes an initial one-dollar loan to a firm with financing cost $R_{I}{ }^{8}$ The initial costs of making the loan are treated as sunk. As in Berglof and Roland (1998), the borrower can exert effort $e \in[0,1]$ to improve the likelihood that the project can yield enough to cover its costs and repay the loan principle and interest, $R_{L}$ (where $R_{L}=1+r_{L}$ ). With probability $e$, the project does so, the loan is repaid, and the borrower's payoff is $Y-R_{L}+B-w(e)$, where $Y$ is the project returns when the project is successful, $B$ is a private benefit to the borrower which is non-

\footnotetext{
${ }^{8}$ Values for parameters $r_{L}, V$, and $B$ can be chosen to make initial loans profitable. Alternatively, following Berglof and Roland (1998), an additional game stage can be added in which the project succeeds or fails with some probability before the firm manager exerts effort to save the project. In that case, the probability of initial success can be arbitrarily adjusted to make the initial loan profitable.
} 
transferable, ${ }^{9}$ and $w(e)$ is the cost of effort. With probability $1-e$, the project fails and the game moves to second stage in which the bank decides whether to liquidate the project to obtain expected collateral value $V$ or to make a second one-dollar refinancing loan at interest rate $r_{L}$ and costing $r_{I}$. We assume $R_{L}-R_{I}>V$, that it is more profitable to successfully refinance than to liquidate. ${ }^{10}$ Finally, if the project is refinanced, the project is successful with probability $\theta$, in which case the project produces return $Y$, the loan is repaid, and the borrower earns $Y-R_{L}+B$. If the project is unsuccessful, both the borrower and bank get nothing. With successful projects, a bank could also collect part or all of its initial loan. The decision nodes of the game are summarized in Figure 1.

The key to the model is its information assumptions. Following the setup of the costly information model, we assume that $\theta$ is drawn from a uniform distribution $\left[\theta_{0}, 1\right]$ and $Y$ is a positive constant greater than $1+\mathrm{r}_{\mathrm{L}}$. The center has no information on firm types but local managers know each firm's $\theta$.

We start from the end of the game and work backwards to study the decentralization decision. With perfect information, the bank refinances only projects for which $\theta R_{L}-R_{I}>V$. Otherwise, the bank liquidates the project, earning $V$. With no information, the bank refinances all projects if and only if the expected return is greater than the collateral value, i.e., $\left(\frac{1+\theta_{0}}{2}\right) R_{L}-R_{I}>V$. Otherwise, it refuses to refinance all projects. It is this refusal that under certain conditions can serve as a credible commitment not to refinance.

When facing the decision of whether to refinance, the bank can always opt for the expected return of $V$ since it can always decide to liquidate all projects. The expected profit from refinancing when the bank is decentralized $(d)$ is the following:

$$
\operatorname{EMax}\left(V, \pi_{2 d}\right)=\left(\frac{\theta^{*}-\theta_{0}}{1-\theta_{0}}\right) V+\left(\frac{1-\theta^{*}}{1-\theta_{0}}\right)\left(\left(\frac{1+\theta^{*}}{2}\right) R_{L}-R_{I}\right), \text { where } \theta^{*}=\frac{V+1}{R_{L}}
$$

\footnotetext{
${ }^{9} B_{1}$ can be interpreted in different ways. For example, Holmstrom and Tirole (1997) define it as the opportunity cost for the firm manager to manage projects diligently.

${ }^{10}$ Collateral need not be so low for refinancing to be viable, since payoffs to refinancing also could include claims on collateral in the event of non-payment or the possibility of recovering earlier loans.
} 
Here, $\theta^{*}$ is the threshold firm type above which the local manager agrees to refinance. The expected profit when lending is centralized $(c)$ is the following:

$$
\operatorname{EMax}\left(V, \pi_{2 c}\right)=\left\{\begin{array}{l}
V \quad \text { if }\left(\frac{1+\theta_{0}}{2}\right) R_{L}-R_{I}<V \\
\left(\frac{1+\theta_{0}}{2}\right) R_{L}-R_{I} \text { if }\left(\frac{1+\theta_{0}}{2}\right) R_{L}-R_{I} \geq V
\end{array}\right.
$$

The return is $\mathrm{V}$ if the expected profit is sufficiently low that the lender liquidates all loans, and is equal to the average return to lending to all types when the center refinances all loans. Comparing (5) and (6), it is easy to see that at the game's second stage, the bank's expected profit is unambiguously higher when lending is informed.

Knowing these decision rules for liquidation and refinancing, we study the effort decision of the borrower. In particular, we are interested in seeing whether there are any conditions under which informed and uninformed lending lead to different effort levels. In the informed case, the borrower's effort depends on whether he or she anticipates a successful project and refinancing, since the borrower earns positive returns with refinancing but gets nothing from a sure loser that is liquidated:

$$
\operatorname{Max}_{e} \pi_{1}=\left\{\begin{array}{l}
e\left[Y-R_{L}+B\right]-w(e)+(1-e) \theta\left[Y-R_{L}+B\right] \quad \text { if } \theta \geq \frac{V+R_{I}}{R_{L}} \\
e\left[Y-R_{L}+B\right]-w(e) \text { if } \theta<\frac{V+R_{I}}{R_{L}}
\end{array}\right.
$$

When lending is uninformed, either all loans are refinanced or no loans are refinanced, depending on whether the expected return from lending is greater than the liquidation value. If uninformed lenders refinance loans, then the borrower's maximization problem is identical to the first equation in (7) regardless of the borrower's type, $\theta$. However, when the lender does not refinance any loans because $\left(\frac{1+\theta_{0}}{2}\right) R_{L}-R_{I}<V$, the borrower's effort is defined by the second equation in (7), again regardless of the borrower's type. We focus on the no refinancing case, for which effort will be higher for some firms when the lender is 
uninformed. ${ }^{11}$ The borrower, instead of reducing effort in anticipation of a possible payoff when the project is refinanced, instead exerts maximum effort because he knows the bank will definitely not refinance. In this way, the bank can improve its loan repayment rate by centralizing refinancing loan approval rights. We denote effort in the decentralized (informed) and centralized (uninformed) cases as $e_{\mathrm{d}}$ and $e_{\mathrm{c}}$. From the above, we have shown that $e_{c} \geq e_{d}$.

Treating the one dollar loan as a sunk cost, the expected profit at the time of making the original loan $\left(E \pi_{0 i}\right)$ is the following:

$$
E \pi_{0 i}=e_{i} R_{L}+\left(1-e_{i}\right) \operatorname{Max}\left(V, E \pi_{2 i}\right)
$$

With probability $e_{i}$, the original loan will be paid in full, and with probability $\left(1-e_{i}\right)$ the borrower will default on the original loan, leaving the lender with either the liquidation value or the expected profit from refinancing the loan $\left(E \pi_{2 i}\right)$. The $i$ subscript denotes the fact that both borrower effort and the expected return from refinancing depend upon whether the refinancing decision is centralized or decentralized $(i=c$ or $d$ ). As noted above, the only situation in which centralization makes sense is when the center can credibly commit not to refinance, or $\left(\frac{1+\theta_{0}}{2}\right) R_{L}-R_{I}<V$ and when doing so increases borrower effort, or $\theta R_{L}-R_{I} \geq V$. In this circumstance, we can write the difference in the expected profits of lending to a firm with type $\theta$ under decentralization versus centralization as follows:

$$
E \pi_{0 d}-E \pi_{0 c}=e_{d} R_{L}+\left(1-e_{d}\right)\left(\theta R_{L}-R_{I}\right)-e_{c} R_{L}-\left(1-e_{c}\right) V
$$

This equation describes the difference in expected profitability of lending to a specific firm under decentralization versus centralization. It is not the difference in the bank's total expected profits, which also reflects differences in the pool of borrowing firms. Here, $e_{d} \leq e_{c}$, and from (7) we know that $e_{d}=e_{d}\left(\theta, R_{L}, Y, B\right)$, and $e_{c}=e_{c}\left(R_{L}, Y, B\right)$.

\footnotetext{
${ }^{11}$ In the former case, centralized lenders always choose to refinance because lending is profitable on average even when the center refinances indiscriminately. In this case, centralization softens the budget constraint, but we consider this outcome unlikely in transition economies in which many projects are risky.
} 
Decentralization reduces borrower effort and the likelihood of repayment of the original loan but increases the expected return in the event the loan is not repaid, leading to an ambiguous sign for (9).

PROPOSITION 2. In the refinancing model, the effect of a higher lending interest rate $\left(R_{L}\right)$ on the relative profitability of lending to a specific firm under decentralization versus centralization is ambiguous. The same relative profitability is greater when there is a lower cost of funds $\left(R_{I}\right)$ or a lower liquidation value $(V)$.

Proof. From (9), we derive the comparative statics:

$$
\frac{\partial\left(E \pi_{0 d}-E \pi_{0 c}\right)}{\partial R_{L}}=\frac{\partial e_{d}}{\partial R_{L}}\left(R_{L}-\left(\theta R_{L}-R_{I}\right)\right)+\left(1-e_{d}\right) \theta+\left(e_{d}-e_{c}\right)
$$

From (7), we know that $\frac{\partial e_{d}}{\partial R_{L}}>0$, so the first term is positive. The second term is also positive, but the third term is negative, since $e_{d} \leq e_{c}$. In addition to the positive incentive effect on firm managerial effort, a higher lending interest rate increases profits for the bank under decentralization whether or not the project is initially successful, because profits also increase for refinanced loans. Under centralization, profits increase only if the project is successful. However, this increase theoretically can outweigh all of the positive profit effects under decentralization if the effort difference (and likelihood of initial project success) under centralization versus decentralization is small enough.

$$
\begin{aligned}
& \frac{\partial\left(E \pi_{0 d}-E \pi_{0 c}\right)}{\partial R_{I}}<0 \\
& \frac{\partial\left(E \pi_{1 d}-E \pi_{1 c}\right)}{\partial V}<0
\end{aligned}
$$

Results (11) and (12) obtain directly from (9) above.

The intuition that the liquidation value has a negative effect on decentralization is clearer if we think of liquidation value as a type of collateral. As Holmstrom and Tirole (1997) have demonstrated, collateral is a substitute for bank monitoring. The use of effective collateral undermines the importance of local information and thus enables the central manager to centralize control rights over lending. 
The effects of parameter changes on the total relative profitability of bank lending under decentralization also depends on how they alter the pool of borrowers for whom decentralization or centralization makes a difference. Focusing on the case in which the center never refinances, this pool is simply all the firms that can obtain loans under decentralization, or for whom $\theta R_{L}-R_{I} \geq V$. Thus, the size of the borrowing pool under decentralization is increasing in $R_{L}$ and decreasing in $R_{I}$ and $V$. How changes in these parameters affect relative profits depends upon whether profits are greater under decentralization versus centralization. If they are greater for decentralization, the composition effects of $R_{L}, R_{I}$, and $V$ on relative bank profits under decentralization are positive, negative, and negative; for $R_{I}$ and $V$, these are the same as the effects on lending profitability to specific firms. If they are greater for centralization, the composition effects are the opposite in sign, leading to ambiguous effects on total bank profitability under decentralization versus centralization. Combining these effects with those discussed in Proposition 2, when decentralization is profitable, increases in $R_{I}$ and $V$ unambiguously make centralization more attractive, but when centralization becomes more profitable the effects become ambiguous. Overall, we posit that when the center does not refinance, the likelihood of decentralization is negatively affected by greater $R_{I}$ and $V$ and ambiguously affected by increases in $R_{L}$.

PROPOSITION 3. In the refinancing model, the likelihood of decentralization of bank lending decreases with higher expected firm performance $\left(\theta_{0}\right)$.

Proof: The condition for centralization to be a viable option is $\left(\frac{1+\theta_{0}}{2}\right) R_{L}-R_{I}<V$. Thus, the higher is $\theta_{0}$, the less likely that commitment to liquidate projects is credible, which increases the likelihood of decentralization. Note that a higher $R_{I}$ and $V$ also reduce the likelihood that commitment not to refinance by the center is credible, reinforcing the earlier predictions.

Finally, we note that the refinancing model makes no predictions on whether the decision to make initial loans is centralized or not. In fact, by the assumptions of the model, there would be no reason to centralize initial lending. 


\subsection{Summary of Model Predictions}

Table 1 summarized the predictions of the two models for how different parameters affect the decentralization decision. Comparative statics for four parameters are derived only from the costly information model. Assuming there are fixed information costs, lending authority is more likely to be decentralized if local managers have advantages in gathering information (smaller $m$ ), the pool of borrowers is larger (larger $N$ ), there is less bank competition (smaller $c$ ), and government influence on lending is less (smaller $G$ ). If information costs are variable only, $N$ and $c$ should have no effects. Predictions for the other four model parameters are not consistent in the costly information model and the refinancing model. The impact of lending interest rates $\left(R_{L}\right)$ is negative in the costly information model but ambiguous in the refinancing model, and the effect of the cost of funds $\left(R_{I}\right)$ is positive in the costly information model but negative in the refinancing model. Firm quality $\left(\theta_{0}\right)$ has an uncertain effect in the costly information model assuming fixed information costs, and a positive effect in the refinancing model. If information costs are variable, the effect of firm quality in the costly information model is negative. Collateral value $(V)$ has an ambiguous effect on decentralization in the costly information model but a negative effect in the refinancing model. Differences in the predictions of the two models yield testable hypotheses for distinguishing which model has greater empirical explanatory power. It is also worth noting that alternative explanations for centralization, such as the influence of local governments over lending (or corruption) do not provide alternative explanations for the specific predictions of the refinancing model for how specific factors affect the delegation decision.

\section{Evidence from China}

\subsection{Data}

The data used in this paper were collected from field surveys conducted by the authors in Jiangsu and Zhejiang provinces during the summer of 1998. Most of the information was garnered from face-to-face interviews with bank managers, firm managers and government leaders at the county and township levels. Select historical data were copied from accounting books. Most of the questions are for the years 1994 and 1997, respectively. These years were chosen to facilitate the study of changes in bank behavior following fundamental reforms introduced in 1994 that increased bank competition and promoted the 
commercialization of financial institutions. Our survey focuses on the township level, the lowest government administrative level in China where branches of the Agricultural Bank of China (ABC) and rural credit cooperatives (RCCs) reside. The ABC is one of China's four specialized banks, with the largest branch network among specialized banks, extending to most but not all townships. The RCCs are cooperatives in name only, not in governance. Originally under the supervision of the ABC, since 1996 they became independent financial institutions and under the direct supervision of the central bank. RCCs are the only financial institutions with branch outlets extending to nearly all townships as well as many villages. $\mathrm{ABC}$ branches and RCCs have been the primary lenders to township and village enterprises (TVEs), the most dynamic sector of China's economy since reforms were launched in 1978 (Oi, 1999). According to the survey data, 78 percent of bank loans within the township were granted by ABC branches and RCCs.

The survey covers 15 counties in the two coastal provinces. Zhejiang and Jiangsu have experienced rapid economic growth in the last two decades, but still contain both welldeveloped and lagging regions. All of the counties were randomly sampled after stratification by region and industrial output per capita. Four townships were randomly selected in each county after stratifying townships by industrial output per capita in 1997. Sixty townships thus were selected in the 15 counties, and government leaders and managers from 59 townships, $57 \mathrm{ABC}$ local branches and 58 RCCs were interviewed. In each county, the $\mathrm{ABC}$ county branch and RCC county association, the parent institutions of $\mathrm{ABC}$ local branches and RCCs, were also surveyed. This paper looks at the allocation of lending authority between county and township branches. A unique feature of the survey is that we collected not only bank data but also matched data from borrowers and local government leaders where the financial institutions were located.

\subsection{Financial Decentralization in China}

One of the goals of financial reform in China was to give financial institutions more autonomy in decision-making and free them from excessive interference by government officials. During the 1990s, considerable progress was made toward this goal. The State Council's "Decision on Reform of the Financial System”, publicized in December, 1993, provided the basis for commercializing China's state-owned specialized banks, including the ABC. This was soon followed by the promulgation of China's first Central Bank Law and 
Commercial Bank Law (Park and Sehrt, 2001; Lardy, 1998). ${ }^{12}$ In 1994 officials began to separate lending responsibilities of different banks, creating policy banks to handle policyoriented lending and leaving commercial banks to loan to businesses on the basis of commercial merit. Leaders also removed restrictions that had previously kept different banks from lending to specific sectors or types of borrowers. For example, ABC branches were allowed to lend to companies in urban areas even if the firms had no connection with agriculture. Finally, the banks were warned that budgetary transfers would no longer cover operational losses. Profits, to a much greater degree, would stay inside the banking system. In sum, the liberalization reforms were designed to create a more market-oriented, profitdriven banking system. Banks were granted much greater autonomy to choose their own business plans of action, reorganize branch structures, and set the control rights of their own branch managers so local outlets would be more responsive to meeting the objectives of the parent institution.

One benefit of our focus on rural financial institutions is that they are less likely to be influenced by government policy concerns than their urban counterparts. While banks such as the Industrial and Commercial Bank of China were obligated to lend to state-owned enterprises, rural financial institutions in general were not subject to policy lending requirements and instead lent willingly to the rapidly emerging rural industrial sector (Che and Qian, 1998). The main exception was the ABC's responsibility to finance the procurement of agricultural commodities by local grain bureaus, but these loans were transferred in 1994 to the newly established Agricultural Development Bank of China. RCCs have never had explicit policy lending responsibilities. Thus, for rural banks, policy lending was mainly in the form of political pressure by local government leaders seeking to support pet projects considered important to the township's economic future.

In our survey, we asked the managers of $\mathrm{ABC}$ county branches and RCC county associations to weigh the relative importance of bank profitability and government policy in lending decisions (Table 2). In 1990, 41.4 percent of the managers reported that local government policies were at least as important as profitability. By 1997, this percentage had dropped dramatically to 3.4 percent. Meanwhile, the percentage of those managers who

\footnotetext{
12 Also, as Lardy (1998) points out, 1993 was a turning point for China's financial reform because of the appointment of Zhu Rongji, then vice premier, to be the president of China's central bank. This increased the powers of the central bank and strengthened government resolve to commercialize the banking system.
} 
claimed that bank profitability was solely important jumped from 3.5 percent in 1990 to 55.2 percent in 1997. These figures demonstrate that, by 1997, managers were focused increasingly on commercial profits as their main objective.

Given these changes, one might think that decentralization would increase as concerns over agency problems diminished. However, just the opposite occurred. To describe trends in decentralization of loan approval authority, we must first introduce the measurements we employ. Distinctions in China's accounting system among the sources of funds used for lending create the need for two sets of loan decentralization measures.

One type of loan in Chinese banks is called zengliang daikuan or "loans using incremental funds." Loans of this type are funds newly available from deposit growth or from transfers from upper level banks, which can be considered new funds borrowed from the banking system. Loans of this type can be extended to either new or existing clients. We refer to loans using incremental funds as "Type I" lending. We define an index variable for decentralization of Type I lending authority which is equal to zero if there is complete centralization, one if local managers have partial discretion to approve loans, and two if they have full discretion. Partial discretion means that loans can be approved by the local manager as long as the loan is smaller than a defined limit.

The other type of loan is cunliang daikuan or "loans using funds from repaid loans." These funds become available when an outstanding loan is repaid to the bank, and can be lent to one of three types of firms: those from which the funds were collected, another existing client of the bank, or a new client. When a local manager has the authority to use funds from repaid loans to lend to another existing client or to a new client, we call this “Type II" lending authority. Type II lending authority ignores the ability to relend to the repaying client, since this is hard to distinguish from fixed credit lines in which the local manager actually does not exercise discretion over the lending decision. ${ }^{13}$ Our variable for measuring Type II lending authority is a categorical variable equal to zero when the local manager cannot lend funds from repaid loans to other clients, and equal to one if he can.

China's financial system has created different categories of loans for several reasons. First, allowing firms to draw from a pool of funds from repaid loans increases the incentive for local managers to improve repayment performance. For this reason, we might expect

\footnotetext{
${ }^{13}$ For example, because of the holdup problem, the bank has to relend to current borrowers should they repay loans that are due.
} 
Type II lending authority to be more decentralized. Second, having a source of funds from new incremental sources allows upper level officials to be more selective with funds that are viewed as more liquid, and hence more valuable. In general, fixed capital loans are more likely to fall under Type I lending authority and working capital loans are more likely to fall under Type II lending authority.

The survey data show clearly that despite the financial reforms described above, between 1994 and 1997, officials in rural financial institutions were actively centralizing lending authority. Hereafter, we use the term county branches or county managers to describe the $\mathrm{ABC}$ county branches or RCC county associations and their management teams, equivalent to the central manager in the theory section. Similarly, we use the term local branches or local managers to describe $\mathrm{ABC}$ township branches or township RCCs and their management teams, which correspond to local managers in the theoretical models. ${ }^{14}$ Among the 29 county managers we interviewed, about half of them stated that the local managers' lending authority had been reduced between 1994 and 1997 (Table 3). In contrast, only four of them (or 13.8 percent) believed local managers had more loan approval authority in 1997 than in 1994. The information about lending authority in 1997 collected from the interviews with local managers shows that county managers completely centralized Type I lending authority in 68.6 percent of ABC local branches and RCCs (Table 3). As expected, Type II lending authority was more decentralized than Type I lending authority, with only 44.0 percent of local branches lacking such control rights.

\subsection{Empirical Specification and Variable Definitions}

We test the theoretical predictions summarized in Table 1 by estimating equations that specify Type I and Type II lending authority in 1997 as a function of variables that represent or proxy for the different model parameters. Although there was an overall move towards centralization, the data show that different localities and different banking systems made different choices. In 1997, there was considerable variation in control rights among bank types, counties, and even among townships within counties (Table 3). Our goal is to

\footnotetext{
14 The $\mathrm{ABC}$ and RCCs are two separate financial institutions operating in rural areas. The national headquarters of the $\mathrm{ABC}$ is in Beijing, and underneath are provincial branches, county branches, and township branches. RCCs only have two levels, county RCC associations and township RCCs. County RCC associations are independent entities.
} 
exploit the cross-sectional variation in the data to test the predictions of the refinancing model.

Following the definitions of Type I and Type II lending described above, we define the categorical decentralization variables $d_{1}$ and $d_{2}$, respectively. The unobserved latent propensity to decentralize lending authority, $\mathrm{d}^{*}$, is defined in reduced form as a function of the model parameters:

$$
d^{*}=d\left(m, N, c, G, R_{L}, R_{I}, \theta, V\right)
$$

We model (13) as a linear function. The categorical variables $d_{1}$ and $d_{2}$ take on different values depending on whether $d^{*}$ is above or below specific threshold levels. Using this assumption, we can estimate (13) as an ordered probit model for Type I lending authority and as a probit model for Type II lending authority.

One of the key implications of the refinancing model is that banks can more credibly commit to liquidating projects if loan approval authority is centralized. In addition to analyzing the determinants of decentralization as described above, we also test this implication by specifying an equation for the determinants of the local manager's likelihood of seizing collateral in the event that loans are not repaid on time. Define $s^{*}$ to be the bank manager's true probability of seizing collateral when non-repayment occurs:

$$
s^{*}=s\left(d, m, N, c, G, R_{L}, R_{I}, \theta, V\right)
$$

The main test is whether decentralization, $d$, has a negative effect on $s^{*}$. Concerned about the endogeneity of $d$, we include all of the variables in the decentralization specification as controls. Although we refrain from formal modeling, it is not hard to theorize how each of these might affect $s^{*}$. $V$ and $c$ are particularly likely to be important factors. First, the greater the liquidation value, or the easier it is to seize collateral, the more likely the manager should be to seize collateral conditional on non-repayment. Second, the effect of competition on refinancing (or not liquidating projects gone bad) is debatable. Petersen and Rajan (1995) argue that bank competition weakens relational lending between lenders and borrowers as the future return of relational lending becomes uncertain, making 
lenders less likely to rescue borrowers that are financially distressed. However Dinc (2000) points out that even if the credit market is competitive, reputation effects may make bank managers more likely to rescue rather than liquidate financially distressed projects. The other covariates, $m, N, G, R_{L}, R_{I}$, and $\theta$ affect the profitability of lending, which determines the opportunity cost of funds, or the opportunity cost of the manager's time, both of which might affect the decision on whether to seize collateral. Because we lack plausible instruments, $d$ may suffer from endogeneity bias. However, we argue that this bias should be upward since central managers should be more likely to decentralize authority to managers who have a greater propensity to seize collateral. This expected bias cannot explain a negative coefficient on the decentralization variable as predicted by the refinancing model.

Although $s^{*}$ is unobserved, we do have information on the categorical variable $s$,

which equals 1 if the bank manager would definitely not seize collateral, 2 if it is unlikely, 3 if it is possible, 4 if seizure is likely, and 5 if the bank manager would definitely seize collateral. We can thus estimate (14) as an ordered probit, with cutoff values for discrete choices estimated along with the coefficients for the independent variables. Our data show that about a half of 111 local managers who responded to the survey question said they would definitely not or were unlikely to seize collateral; more than one fourth (27 percent) reported that there was a possibility that they would seize collateral; and less than one fourth $(22.5$ percent) said they would very likely or definitely seize collateral.

\section{Independent Variables}

Table 4 summarizes the mean values for independent variables used in the empirical analysis as well as the means for banks whose managers have different levels of lending authority. Here, we briefly explain how each variable is constructed and its appropriateness for measuring the parameter of interest. Unless otherwise noted, all variables reflect township bank branch information.

To measure information cost $(m)$, we include the average education level and age of local managers of the same bank type in the same county (EDU and $A G E$ ), and an indicator of previous loan performance (LNPERF). We avoid including the local manager's own education level and age because of concern that the assignment of managers to different branches within the county is not random. For example, if educated and experienced 
managers are more likely to be sent to problem areas, we might misinterpret the effect of manager characteristics on decentralization of lending authority. Although county managers have great discretion in assigning managers to different townships in their county, there is no movement of local managers across counties. The county means thus reflect the average characteristics of the pool of local managers in the county. ${ }^{15}$ Past loan performance (LNPERF), defined as the proportion of a local branch's borrowing firms that repaid loans on time in 1996, should reflect the ability of local managers to evaluate and monitor loans. We use 1996 rather than 1997 data to reduce potential endogeneity. We recognize that LNPERF might also pick up the effects of unobserved firm quality or government influence even though measures of both are included in the estimation.

The number of firms $(N)$ is based on estimates by local managers of the total number of current and potential borrowing firms (FMNUM). ${ }^{16}$

Bank competition $(c)$ is measured by loan market share of other banks (COMP). The greater the share, the greater the competition. Local managers were asked to estimate the market share of lending for both themselves and their competitors. In townships with both $\mathrm{ABC}$ branches and RCCs, we measure the market shares of each by taking the average of the two estimated market shares.

To measure government influence on lending $(G)$, we include a variable constructed from the survey responses of county managers summarized in Table 2 (GOV). We drop data on banks that report "others" in Table 2.

The lending interest rate $\left(R_{L}\right)$ is defined by the annual percentage yield of a sixmonth loan at the end of 1997 (LNRATE). We assume that these rates are taken as exogenous by county managers. During the period of study, the government set loan and deposit rates nationally. Local branches including township ABC branches and RCCs were allowed to adjust rates within narrow bands, but these adjustments were typically decided upon by upper level branches. ${ }^{17}$ The data shows no variation in interest rates charged by

\footnotetext{
15 There remains possible county-level endogeneity from the replacement of old managers with new managers that have no previous experience as managers and different levels of education, but this is unlikely to lead to substantial bias given the relatively fixed nature of promotion procedures and the difficulty of relocating large number of managers to other jobs before retirement.

${ }^{16}$ In China, the definition of a firm is based on the number of employees. Any business that hires more than seven people must be registered as a firm. The total number of firms includes township and village-run enterprises as well as private enterprises.

${ }^{17} \mathrm{On}$ average, the actual lending rates of $\mathrm{ABC}$ county branches were 10 or 20 percent above the base rate set by the central bank while those of RCC county associations were 40 or 50 percent above the base rate.
} 
township branches of the same bank within the same county. Thus, within a county the lending interest rates are not endogenous to unobserved township characteristics. The unified county interest rates contrast with the ability of county branches to make different decentralization decisions for different township branches. The interest rate of a county bank also are strongly dictated by directives of provincial branches of the same bank, the county People's Bank of China, and under competitive pressure from other banks operating in the county pursuing many of the same customers (e.g., Industrial and Commercial Bank, Construction Bank).

We include three variables to measure the cost of funds $\left(R_{I}\right)$. The first is the share of long-term deposits over total deposits (COST) which reflects the average cost of funds since all deposit rates are fixed by the central bank and the interest rates for long-term deposits (e.g., certificates of deposit) are higher than short-term deposits. Local branches might also have access to funds from their county branches which they can borrow at a low internal borrowing rate. Under loan-deposit ratio management, this access likely decreases as the loan-deposit ratio increases. We include the planned loan-deposit ratio of the county branches for 1997 (CLDRO) and the actual loan-deposit ratios of local branches at the end of 1996 (LLDRO) to reflect the likelihood of internal borrowing. We again use the 1996 value instead of the year-end 1997 value to reduce endogeneity problems.

Two variables describe firm quality $\left(\theta_{0}\right)$. The first is the share of potential borrowing firms that the local manager says he would be willing to finance if the firm applied for a loan (FMTYPE). It is possible that a local manager facing poor loan performance might complain about firm quality and thus underestimate it. To account for this potential bias, we run a linear regression for (13) in which we instrument using the share of profitable township enterprises based on township government accounting records. ${ }^{18}$ The fact that the sign of FMTYPE remained the same after instrumentation suggests that the measurement error is negligible. A second variable measuring firm performance is industrial output value per capita in the township in 1996 (IOPERC). Since the specification already includes total number of firms and quality of firms, this variable captures the average scale of enterprises in the township. Local managers may prefer larger firms because all things equal, large firms

\footnotetext{
18 Our survey collected some key information about each township enterprises that existed in 1994 and were still operating in 1997. Based on the data, we can calculate the share of profitable township enterprises. The reason we din not use this variable to represent the firm quality is that it excludes private enterprises.
} 
can more easily raise cash during periods of difficulty and might receive implicit support from local government officials. An additional identification problem related to firm quality is that the theory suggests that if centralization reduces refinancing, managers may exert more effort and firm performance should improve. While we lack plausible instruments to deal effectively with this problem, we can sign the bias. The simultaneity should lead us to underestimate the effect of firm quality on decentralization.

Collateral value $(V)$ is measured by a question asked of local managers about liquidation cost $(L I Q)$ and by the percentage of local firms that are private (PESHARE). Liquidation cost is measured on a scale of 1 to 5 , where 1 indicates that high liquidation cost was a very serious problem and 5 means liquidation cost was not a problem at all. The survey finds that 65.8 percent of local managers chose 1 or 2 (very serious and serious, respectively). Only 25.3 percent selected 5 (not a problem). Here, a higher ranking for LIQ represents lower liquidation costs or higher expected collateral value $(V)$ if we define expected collateral value to be the product of the quality of successfully seizing collateral and the value of that collateral. However, LIQ does not itself directly measure the value of collateral, and so does not fully correspond to the theoretical parameter V. We replaced missing values with county averages for the same bank type, since we expect local branches in the same county to share a common court and other institutions affecting liquidity costs. Inclusion of PESHARE captures the greater political difficulty that bank managers have seizing publicly owned assets (Park and Shen, 2003).

We include bank dummies (BANK: 0=Township RCCs and 1=ABC local branches) and provincial dummies (PROV) to capture unobserved institutional differences between bank types and regions. Because RCCs have a more extensive branch network, we expect their information to be better than that of $\mathrm{ABC}$ branch managers. All estimation results include standard errors adjusted for clustering by county.

\subsection{Empirical Results: Decentralization}

Our empirical results confirm many of the predictions of the refinancing model. For many independent variables, this is apparent even in cross-tabular data on Type I and Type 
II lending authority (Table 4). ${ }^{19}$ Older, presumably more experienced, managers are more likely to have control rights, although educated managers are less likely, perhaps because younger managers tend to be more educated. A bank's past loan performance has a positive relationship with decentralization; bank competition is negatively correlated; lending interest rates are positively correlated, firm quality variables are positively correlated, and government influence is negatively correlated.

The main estimation results for the determinants of Type I and Type II lending authority are presented in Tables 5 and 6. For each type of lending authority we report estimates for both a "full" sample in which missing values for a number of variables are replaced by county means and for a "pure" sample which excludes all observations with any missing values. For each sample, we report specifications with and without $G O V$ in order to see how robust the refinancing model predictions are to controlling for the main alternative explanation for centralization. The tables report marginal effects of changes in the independent variables on the probability that lending authority is partly or fully decentralized. Tables with coefficient estimates are available from the authors upon request. Overall, the results strongly confirm the predictions of the refinancing model. For Type I lending authority, all of the coefficients are of the expected sign and most are statistically significant. The coefficients on education and age, our measures of information cost, are both positive in all specifications. Both are statistically significant at the 10 percent level in the full specification (1) and education is also significant in specifications (3) and (4). Managers with degrees above high school are about 40 percent more likely to have Type I lending authority and an extra year of experience increases the probability of decentralization by 2-3 percent. Past loan performance is positive when GOV is controlled for, but not statistically significant. Firm number has a statistically significant but small effect on the likelihood of decentralization, with a 10 percent increase in firms evaluated at the sample mean increasing the likelihood of decentralization by only half a percentage point. Bank competition significantly reduces the probability of decentralization in three of four specifications; a one percent reduction of lending market share reduces the probability of decentralization by $0.45-0.60$ percent. Government influence has a negative effect on

\footnotetext{
19 The incentive scheme may also have played a role in the course decentralization. However, the impact of incentives may be ambiguous. Using the share of bonus in annual income of local bank employees to represent the incentives, we found that the incentives are negatively associated with decentralization.
} 
decentralization as expected. Although the magnitude of the effect is large, a one rank change in a five-rank ordinal scale reducing the likelihood of decentralization by 11-18 percent, the coefficients are not statistically significant in any specification.

The empirical results show that all those variables that have opposite predictions in the costly information model and refinancing model are consistent with the predictions of the refinancing model. The coefficients on our measures of the lending interest rate, the cost of funds, firm quality, and collateral value (or the liquidation cost) that are statistically significant all are consistent with the refinancing model. Even when the coefficients are not statistically significant, they have the predicted sign. The share of long-term deposits is statistically significant in specifications (3) and (4), a one percent increase reducing the likelihood of decentralization by 0.6-0.9 percent. The effect of loan-deposit ratios, both at the local (township) and central (county) levels are highly statistically significant in all specifications. A one percent increase in local (central) loan-deposit ratio reduces the probability of decentralization by $0.4-0.8(1.6-2.7)$ percent. Thus central liquidity has an affect roughly three times that of local liquidity. The quality of the borrowing pool, measured by firm quality--the percent of good, or credit-worthy firms in the township (FMTYPE), and firm quantity--industrial output per capita (IOPERC), has a positive effect on decentralization in all cases. The coefficient on FMTYPE is significant in all specifications and the coefficient on IOPERC is statistically significant in specification (4). A one percent increase in FMTYPE increases the probability of decentralization by 0.7-0.9 percent. Finally, both measures of liquidity value, LIQ and PESHARE, have expected negative signs, with LIQ statistically significant in specifications (3) and (4).

The bank dummy has a consistent negative sign and is statistically significant, indicating that RCCs are more decentralized in lending decisions than the ABCs ceteris paribus. We offer two possible reasons to explain the difference. First, there may be a size effect. As a national financial institution, the ABCs are better integrated into regional and national financial markets, providing more lending or other investment opportunities. Second, RCCs have a larger branch structure within the township so are likely to have advantages in information gathering.

Next, we turn to the results for Type II lending. We expect differences with Type I lending to reflect the fact that Type II lending authority considers the center's desire to provide an incentive for managers to exert effort to collect outstanding loans rather than 
simply roll over bad loans. ${ }^{20}$ Type I lending authority, on the other hand, governs the use of incremental funds, which are independent of previously lent funds. Not surprisingly, the results for Type II lending authority generally are not as strong as for Type I lending authority. However, many of the differences can be explained by the additional repayment motive guiding Type II lending authority.

The results for Type II lending authority for the most part are consistent with the refinancing model. The signs are all as expected, with the exception of mixed signs for the lending interest rate, for which the signs were wrong for Type I lending, mixed signs for the share of long-term deposits, and a positive sign for difficulty in seizing collateral, which is statistically significant in specification (3). Regarding the latter result, the reversal of sign for liquidation value $(L I Q)$, we speculate that since Type II lending authority is intended to provide a positive incentive for managers to enforce loan repayment, decentralization may be complementary to having a credible threat to seize collateral, or an ability to enforce.

Otherwise, the main differences between the determinants of Type I and Type II lending authority are differences in the statistical significance and magnitude of the coefficients. While education is important for Type I lending, it is statistically insignificant for Type II lending. At the same time, the coefficient for age is twice as high and statistically significant, suggesting that experience is a more important consideration for Type II lending, perhaps reflecting its greater value in getting loans repaid. The coefficient for loan performance is also much greater for Type II lending, and statistically significant in specification (3), and the effect of government influence is also greater and now statistically significant. Both suggest that decentralization is less likely if the center perceives there is little hope of recovering repayment even if the local manager has control rights over repaid funds, because the manager's previous performance has been poor and/or local leaders are influential. The importance of loan-deposit ratios seems less pronounced for Type II lending, perhaps because the higher cost of funds magnifies the value of repaid funds, increasing the incentive to enforce repayment associated with Type II lending authority. Finally, the coefficient on FMTYPE is much smaller and statistically insignificant, perhaps

\footnotetext{
20 Our survey shows that because of insufficient guarantees and high liquidation costs, of the non-performing loans that existed by the end of 1996, only about 15 percent of them were recovered during the year of 1997. For those loans newly made to TVEs during 1997, on average 56.5 percent of them were just rolled over. During the same period, 47.3 percent of new loans granted to private enterprises belonged to the same category. Some newly privatized enterprises inherited loans from TVEs. For that part of loans, the repayment rate was not improved a lot even if there were transferred from a collective enterprise to a private one.
} 
reflecting the fact that repayment incentives have higher priority where there are more bad firms. Thus, most of the differences in the results for Type II lending are consistent with an added concern about effort incentives to recover outstanding loans.

In concluding our discussion of the results for the determinants of decentralization, we make two observations. First, all of the predicted effects coming from the refinancing model are confirmed and are statistically significant. This is true even when the costly information model with agency yields ambiguous or opposite predictions. We are unaware of alternative explanations that can explain the same pattern of results. Second, the variable measuring government influence has a statistically insignificant coefficient for Type I lending, and its inclusion does not appreciably alter the other coefficients for either Type I or Type II lending. This suggests agency problems cannot explain the patterns of decentralization that we observe, and that omitted variables related to agency are unlikely to be biasing our estimates. One explanation for the dominance of the refinancing model is that, after the rapid expansion of the rural industrial sector in the early 1990s, competition within and outside the sector reduced new entry. Most recent new loans were in fact directed to finance (or refinance) existing firms. An overall decline in the performance of township and village enterprises in the mid-1990s also led to a large increase in firms needing refinancing, and so how such requests were handled became a key concern of county branch managers in delegating control rights over lending.

\subsection{Empirical Results: Collateral Seizure}

Next, we present the results for the ordered probit estimates of the likelihood of seizing collateral when loans are not repaid on time (Table 7). As described earlier, our goal is to test whether centralization of lending authority actually increases the credibility of threats to liquidate projects and seize collateral. Our hypothesis is that the decentralization variable will have a negative effect on the probability that collateral will be seized when repayment is late. We conducted separate estimations including Type I and Type II lending variables separately and in combination, and found significant effects only for Type I lending authority, which we report in Table 7. The lack of effects for Type II lending is not surprising since Type II lending authority increases incentives of managers to enforce repayment and follow through with threats to seize collateral. As before, we report specifications for both the "full" and "pure" samples. We also report results for 
specifications with all of the control variables from the decentralization equations and for a more parsimonious specification that includes what we deem to be essential controls, the liquidation value variables (LIQ and PESHARE) and the competition variable (COMP).

The main result is that the coefficient for Type I lending authority is negative and statistically significant in three of the four specifications. Decentralization reduces the likelihood of collateral seizure by $10-15$ percent. The insignificant result for specification (3) suggests that identification is weakened when the sample is small and the number of independent variables is large. ${ }^{21}$ In interpreting this result, a main concern is the potential for simultaneity bias because county managers could allocate control rights conditional on knowledge of the refinancing tendency of local managers. However, the direction of such bias can be signed since in general managers should decentralize more when the local manager is less likely to refinance. But this should lead to upward bias in the parameter estimates, leading to a more positive relationship between decentralization and collateral seizure. This only makes it harder to arrive at a statistically significant negative coefficient, which is consistent with our refinancing model. Although we cannot rule out remaining bias from omitted variables, we find it difficult to think of ones which could produce the strong relationships we see in the data. Unfortunately, we lack plausible instruments to more convincingly identify the effect of control rights on the ability to credibly refuse refinancing.

Most of the signs for other variables are consistent with expectations, and here we discuss just a few results of interest. Liquidation value has a positive sign across specifications and is statistically significant in specifications (1) and (3). The strong negative sign for bank competition lends support to Dinc (2000) who emphasizes the beneficial aspects of competition for reputational lending. Most of the variables related to the cost of refinancing have the expected signs and are statistically significant. One exception is that the signs on the firm quality variables are negative and significant in some cases. Perhaps the expected return of rescuing a distressed firm is higher in an economy in which there are more good firms.

\section{Conclusions}

\footnotetext{
${ }^{21}$ In a joint estimation of the ordered probits for Type I lending (specification 3) and collateral seizure (specification 3) that allowed for jointly normal, correlated errors, the sign on the decentralization variable became negative and nearly statistically significant. Other joint specifications failed to converge. This result confirms that bias if anything is against finding a negative relationship.
} 
China's financial reforms have aimed to promote greater independence and market orientation of financial intermediaries through increased bank competition, reduction of policy loans, and stronger profit incentives. Decentralization of managerial authority in such settings should help improve the efficiency of resource allocation by giving local managers greater incentives to screen loans effectively and enforce repayment. This is especially true when institutions capable of providing independently verifiable information on credit-worthiness and collateral values are lacking, which increases information asymmetry between the center and local levels and makes local information more valuable.

In China, however, banks responded to reform by centralizing rather than decentralizing lending authority. In this paper, we provide a new explanation for the benefits of centralization in China, as well as in other developing and transition economies. When banks have difficulty credibly committing to not refinance projects when firms are in distress, centralization can help by reducing available information. We present a costly information model of decentralization, including several simple extensions, as well as a refinancing model, which extends the first model to capture dynamic incentive problems, to illustrate potential explanations for decentralization in China and make precise theoretical predictions about how key features of the banking and economic environment should affect the decentralization of financial institutions. For example, the refinancing model predicts that greater decentralization should be associated with lower cost of funds, better firm quality, and lower collateral values, while other explanations yield opposite or inconclusive predictions.

Then, using unique data from surveys conducted by the authors of rural financial institutions in China, we take the theory to the data. This exercise provides strong empirical support for the refinancing model. The more frequently conjectured reason for centralization, agency or corruption problems, is not well supported by the data or by the trends of decreasing policy influence and increasing centralization over time. Nor can it explain why such problems cannot be solved by directly addressing the incentive problem, which avoids the costly loss of local information.

The lack of mature institutions to support the negotiation and enforcement of lending contracts creates a paradox. On the one hand, it increases the value of local information embodied in the local manager's knowledge and experience because independent verifiable information sources are lacking. This increases the value of 
decentralization. On the other hand, it also exacerbates the refinancing problem when lending authority is delegated by making liquidation of projects difficult. When the refinancing problem becomes sufficiently important, it precludes decentralization in exactly those institutional contexts for which the loss of local information is most costly. This may be especially hard on the nascent private sector, for which local information may be particularly important for quality assessments. The poor information of central bank managers can help explain the frequent complaints in China that banks have stopped lending as well as the complaints of bankers that good projects are impossible to find. In more developed market systems, decentralization may not be a critical concern because so much of a firm's information is verifiable through audited financial statements, credit histories, etc. We conclude that financial liberalization is not a panacea. Effective financial intermediation requires the creation of effective supporting institutions, a process which is slow and gradual. 


\section{References}

Aghion, P., Tirole, J., 1997. Formal and Real Authority in Organizations. Journal of Political Economy 105, 1-29.

Berglof, E., Roland, R., 1998. Soft Budget Constraints and Banking in Transition Economies. Journal of Comparative Economics 26, 18-40.

Buch, Claudia M., 1996. Creating Efficient Banking Systems: Theory and Evidence from Eastern Europe (J.C.B. Mohr (Paul Siebeck) Tubingen).

Che, J., Qian, Y., 1998. Institutional Environment, Community Government, and Corporate Governance: Understanding China's Township and Village Enterprises. Journal of Law, Economics, and Organization 4, 1-23.

Cho, Y. J., 1986. Inefficiencies from Financial Liberalization in the Absence of WellFunctioning Equity Markets. Journal of Money, Credit, and Banking 8, 341-344.

Cremer, J., 1995. Arm's Length Relationships. Quarterly Journal of Economics 110, 275-295.

Dinc, S., 2000. Bank Reputation, Bank Commitment, and the Effects of Competition in Credit Markets. Review of Financial Studies 13, 781-812.

Dewatripont, W., Maskin, E., 1995. Credit and Efficiency in Centralized and Decentralized Economies, Review of Economic Studies 62, 51-555.

Haggard, Stephan, and Chung H. Lee (ed.), 1995. Financial Systems and Economic Policy in Developing Countries (Ithaca and London: Cornell University Press).

Holmstrom, B., Tirole, J., 1997. Financial Intermediation, Loanable Funds, and the Real Sector. Quarterly Journal of Economics 112, 663-691.

Jin, H., Qian, Y., 1998. Public versus Private Ownership of Firms: Evidence from Rural China. Quarterly Journal of Economics 113, 773-808.

Klibanoff, P., Morduh, J., 1995. Decentralization, Externalities, and Efficiency. Review of Economic Studies 62, 223-247.

Koford, K., Tschoegl, A. E., 1997. Problems of Bank Lending in Bulgaria: Information Asymmetry and Institutional Lending. Working paper, the Wharton School, University of Pennsylvania.

Kornai, J., 1986. The Soft Budget Constraint. Kyklos 39, 3-30.

Laffont, J., Martimort, D.,1998. Collusion and Delegation. RAND Journal of Economics 29, 280-305. 
Lardy, Nicholas, 1998, China's Unfinished Economic Revolution (Washington D.C.: Brookings Institution Press).

Li, D., Li, S., 1996. Financial Distress of China's State-owned Enterprises: A Theoretical Analysis and Policy Implications. In: D. Xu and J. Wen (Eds.), Reform of State-owned Enterprises in China, China Economic Press.

Naughton, B., 1995. Growing Out of the Plan: Chinese Economic Reform, 1978-1993 (New York: Cambridge University Press).

Park, A., Sehrt, K., 2001. Tests of Financial Intermediation and Banking Reform in China. Journal of Comparative Economics 29, 608-644.

Park, A., Shen, M., 2003. Joint Liability Lending and the Rise and Fall of China's Township and Village Enterprises. Journal of Development Economics 71, 497-531.

Petersen, M., Rajan, R., 1995. The Effect of Credit Market Competition on Lending Relationships. Quarterly Journal of Economics 110, 407-443.

Qian, Y., 1994. Financial System Reforms in China: Lessons from Japan's Main Bank System. In: M. Aoki and H. Patrick (Eds.), The Japanese Main Bank System: Its Relevance for Developing and Transforming Economies. Oxford University Press, pp. 552-591.

Qian, Y., Roland, G., 1998. Federalism and the Soft Budget Constraint. American Economic Review 88, 1143-1162.

Schmidt, R., 1998. Banking on the Transition. In: J. M. Fanelli and R. Medhora (Eds.), Financial Reform in Developing Countries, St. Martin's Press, Inc..

Strausz, R., 1997. Delegation of Monitoring in a Principal-Agent Relationship. Review of Economic Studies 64, 337-357.

Svejnar, J., 1990. Productive Efficiency and Employment. In W. Byrd and Q. Lin (Eds.), China's Rural Industry: Structure, Development, and Reform. Washington, D.C.: The World Bank. 


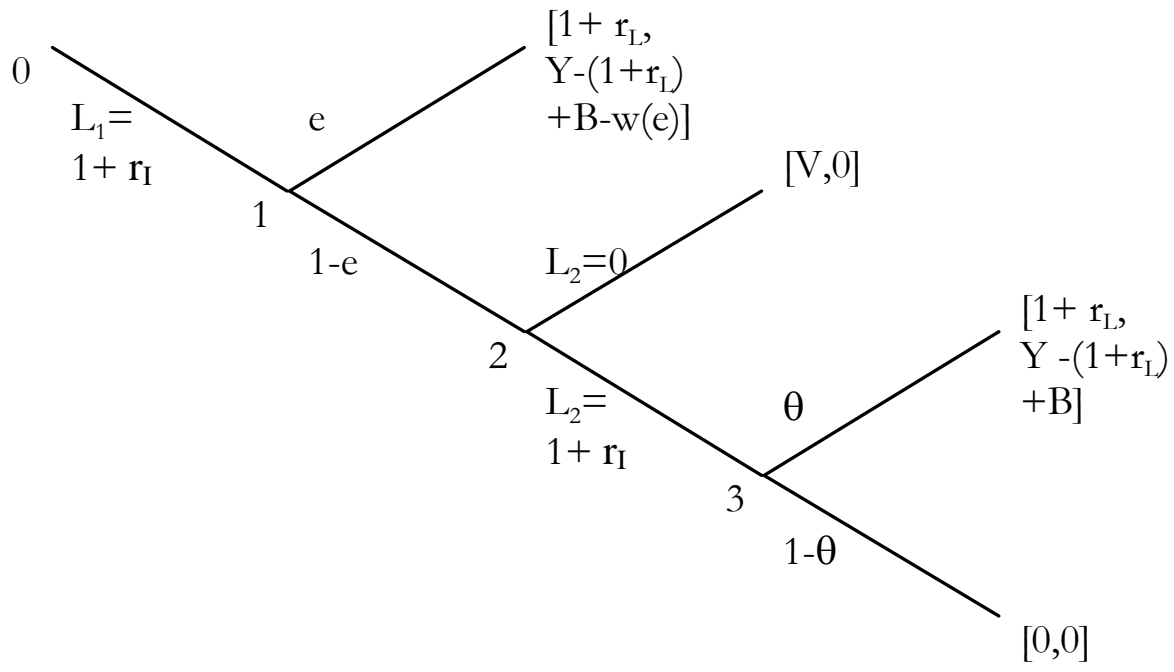

Figure 1 Refinancing Game Tree 


\section{Table 1}

\section{Theoretical Predictions on the Determinants of Financial Decentralization}

\begin{tabular}{lccc}
\hline & $\begin{array}{c}\text { Costly Information } \\
\text { Model and Extensions }\end{array}$ & $\begin{array}{c}\text { Refinancing } \\
\text { Model }\end{array}$ & $\begin{array}{c}\text { Overall } \\
\text { Predictions }\end{array}$ \\
\hline Information cost $(m)$ & - & & - \\
Number of firms $(N)$ & + & & - \\
Banking competition $(c)$ & - & & - \\
Government influence $(\mathrm{G})$ & - & $?$ & $?$ \\
Lending interest rate $\left(\mathrm{R}_{\mathrm{L}}\right)$ & - & - & $?$ \\
Cost of funds $\left(\mathrm{R}_{\mathrm{I}}\right)$ & + & + & $?$ \\
Firm quality $\left(\theta_{0}\right)$ & $?$ & - & $?$ \\
Collateral or liquidation value & $?$ & & $?$ \\
$(V)$ & &
\end{tabular}

Note: All results assume that information costs are fixed. If information costs are variable, the number of firms $(N)$ and banking competition $(c)$ have no effect on decentralization and for the costly information model the effect of better firm quality $\left(\theta_{0}\right)$ is negative rather than uncertain.

Table 2

\section{Relative Importance of Profits and Government Policy in Lending}

\begin{tabular}{lcc}
\hline & 1990 & 1997 \\
\hline Bank profitability was solely important & 3.5 & 55.2 \\
Bank profitability was more important than government policy & 51.7 & 35.5 \\
Bank profitability and government policy were equally important & 13.8 & 3.4 \\
Government policy was more important than bank profitability & 20.7 & 0 \\
Government policy was solely important & 6.9 & 0 \\
Others & 3.4 & 6.9 \\
\hline
\end{tabular}

Note: This table reports subjective assessments by managers of ABC county branches and RCC county associations. Local government leaders were asked the same questions and similar results were obtained.

Table 3

\section{Decentralization of Lending Authority to Local managers}

Changes in Lending Authority between 1994 and $1997^{\mathrm{b}}$

Type I Type II ${ }^{\text {a }}$

Shrunk

No change

\section{7}

34.5

Expanded

13.8

Observations

Lending Authority in 1997 c

Full centralization (no lending authority)

Partial decentralization (defined limit on lending authority)

Full decentralization (no limits on lending authority)

66.1

29.6

4.3

Observations

115

44.0

56.0

${ }^{\text {a }}$ Data does not allow us to distinguish between partial and full decentralization.

b Data collected from interviews with managers of ABC county branches and RCC County Associations.

c Data collected from interviews with managers of ABC local branches and RCCs. 
Table 4

Summary of Independent Variables

\begin{tabular}{|c|c|c|c|c|c|c|c|}
\hline \multirow[t]{2}{*}{ Parameter } & \multirow[t]{2}{*}{ Definition (variable name) } & \multirow[t]{2}{*}{$\begin{array}{c}\text { Full } \\
\text { sample }\end{array}$} & \multicolumn{3}{|c|}{$\begin{array}{l}\text { Type I lending authority } \\
\text { (CONTROL1) }\end{array}$} & \multicolumn{2}{|c|}{$\begin{array}{l}\text { Type II lending authority } \\
\text { (CONTROL2) }\end{array}$} \\
\hline & & & 0 & 1 & 2 & 0 & 1 \\
\hline$m$ & Local manager's education background ad (EDU) & 0.62 & 0.64 & 0.57 & 0.52 & 0.72 & 0.54 \\
\hline$m$ & The age of local managers ${ }^{\mathrm{d}}(A G E)$ & 39.22 & 38.86 & 39.94 & 40.04 & 37.90 & 39.94 \\
\hline$m, \theta$ & Share of borrowing firms repaid loans timely in 1996 (LNPERF) & 0.67 & 0.66 & 0.69 & 0.76 & 0.59 & 0.74 \\
\hline$N$ & Total number of firms in the community in 1997 (FMNUM) & 158.40 & 144.03 & 205.21 & 70.00 & 129.91 & 180.86 \\
\hline$c$ & Share of loans made by other lenders in 1997 (COMP) & 0.61 & 0.64 & 0.57 & 0.27 & 0.62 & 0.59 \\
\hline$G$ & The role of government policy in lending bd (GOV) & 1.54 & 1.61 & 1.44 & 1.00 & 1.56 & 1.48 \\
\hline$R_{L}$ & Lending interest rate by the end of $1997 \mathrm{~d}$ (LNRATE) & 0.095 & 0.093 & 0.098 & 0.100 & 0.093 & 0.095 \\
\hline $\mathrm{R}_{I}$ & Share of long-term deposits over total deposits in 1997 (COST) & 0.688 & 0.699 & 0.660 & 0.734 & 0.681 & 0.700 \\
\hline $\mathrm{R}_{I}$ & Loan-deposit ratio in local branches by the end of 1996 (LDRO) & 0.679 & 0.684 & 0.682 & 0.596 & 0.671 & 0.683 \\
\hline $\mathrm{R}_{I}$ & Loan-deposit ratio in county bank branches $\mathrm{d}(C L D R O)$ & 0.697 & 0.700 & 0.688 & 0.694 & 0.732 & 0.668 \\
\hline$\theta$ & Qualified borrowing firms over all firms in townships (FMTYPE) & 0.42 & 0.37 & 0.47 & 0.77 & 0.39 & 0.44 \\
\hline$\theta$ & Industrial output value per capita in 1996 (1,000 yuan per capita) (IOPERC) & 21.33 & 2.13 & 2.35 & 1.62 & 19.53 & 23.98 \\
\hline$V$ & Liquidation value ${ }^{\mathrm{c}}(L I Q)$ & 2.50 & 2.60 & 2.41 & 2.28 & 2.53 & 2.47 \\
\hline \multirow[t]{2}{*}{$V$} & Share of output value from private enterprises in 1996 (PESHARE) & 0.26 & 0.22 & 0.33 & 0.175 & 0.32 & 0.17 \\
\hline & Total observations & 115 & 77 & 35 & 5 & 48 & 61 \\
\hline
\end{tabular}

a $1=$ with degrees above high school; $0=$ otherwise.

b $1=$ Bank profitability was solely important; $2=$ Bank profitability was more important than government policy; $3=$ Bank profitability and government policy were equally important; 4= Government policy was more important than bank profitability; $5=$ Government policy was solely important.

c $1=$ liquidation cost is extremely high; $2=$ very high; $3=$ high; $4=$ modestly high; $5=$ normal.

d County-level variable. All other variables are township variables 
Table 5

Marginal Effects of Determinants of Type I Lending Authority

\begin{tabular}{|c|c|c|c|c|c|c|c|c|}
\hline & \multicolumn{2}{|c|}{ (1) } & \multicolumn{2}{|c|}{ (2) } & \multicolumn{2}{|c|}{ (3) } & \multicolumn{2}{|c|}{ (4) } \\
\hline & $\begin{array}{c}\text { Marginal } \\
\text { Effects }\end{array}$ & $\begin{array}{c}\text { Standard } \\
\text { Errors }\end{array}$ & $\begin{array}{c}\text { Marginal } \\
\text { Effects }\end{array}$ & $\begin{array}{c}\text { Standard } \\
\text { Errors }\end{array}$ & $\begin{array}{c}\text { Marginal } \\
\text { Effects }\end{array}$ & $\begin{array}{l}\text { Standard } \\
\text { Errors }\end{array}$ & $\begin{array}{l}\text { Marginal } \\
\text { Effects }\end{array}$ & $\begin{array}{c}\text { Standard } \\
\text { Errors }\end{array}$ \\
\hline EDU & $0.386^{*}$ & 0.233 & 0.351 & 0.257 & $0.460^{* *}$ & 0.224 & $0.412^{*}$ & 0.237 \\
\hline AGE & $0.030^{*}$ & 0.018 & 0.030 & 0.019 & 0.022 & 0.020 & 0.019 & 0.020 \\
\hline LNPERF & 0.021 & 0.182 & -0.025 & 0.176 & 0.017 & 0.208 & -0.122 & 0.183 \\
\hline FMNUM & $0.0003^{*}$ & 0.000 & 0.0003 & 0.000 & $0.0003^{*}$ & 0.000 & $0.0003^{*}$ & 0.000 \\
\hline COMP & $-0.446^{*}$ & 0.262 & $-0.529 * *$ & 0.245 & -0.500 & 0.392 & $-0.603^{*}$ & 0.337 \\
\hline GOV & -0.114 & 0.094 & & & -0.182 & 0.131 & & \\
\hline LNRATE & -11.867 & 14.692 & -17.453 & 16.882 & 10.896 & 15.493 & 8.526 & 15.711 \\
\hline cosT & -0.263 & 0.343 & -0.005 & 0.259 & $-0.939 * *$ & 0.444 & $-0.623^{* * *}$ & 0.220 \\
\hline LLDRO & $-0.416^{*}$ & 0.227 & $-0.369 *$ & 0.216 & $-0.810^{* *}$ & 0.377 & $-0.720^{* *}$ & 0.348 \\
\hline CLDRO & $-1.625^{* * *}$ & 0.627 & $-1.881 * * *$ & 0.696 & $-2.190 * * *$ & 0.788 & $-2.707 * * *$ & 0.856 \\
\hline FMTYPE & $0.660^{* *}$ & 0.271 & $0.701^{* *}$ & 0.284 & $0.849^{* * *}$ & 0.288 & $0.871 * * *$ & 0.305 \\
\hline IOPERC & 0.005 & 0.031 & 0.017 & 0.026 & 0.035 & 0.031 & $0.055^{*}$ & 0.030 \\
\hline LIQ & -0.089 & 0.056 & -0.086 & 0.056 & $-0.104 * *$ & 0.049 & $-0.107 * *$ & 0.050 \\
\hline PESHARE & -0.067 & 0.344 & -0.028 & 0.361 & -0.403 & 0.420 & -0.321 & 0.424 \\
\hline BANK (0=RCCs; $1=\mathrm{ABC})$ & $-0.497 * * *$ & 0.149 & $-0.533^{* * *}$ & 0.155 & $-0.399 * *$ & 0.204 & $-0.393^{* *}$ & 0.193 \\
\hline PROV (0=Zhejiang; $1=$ Jiangsu) & $-0.315^{*}$ & 0.177 & $-0.370 * *$ & 0.180 & -0.300 & 0.258 & -0.370 & 0.271 \\
\hline Observations & 84 & & 84 & & 64 & & 64 & \\
\hline
\end{tabular}

Notes: The dependent variable is decentralization of Type I lending authority, defined as follows: $1=$ full centralization, $2=$ partial decentralization, $3=$ full

decentralization. Marginal effects are the effects on the likelihood of decentralization (partial or full) rather than full centralization, based on ordered probit estimates evaluated at sample means. Numbers in parentheses are standard errors. *,**, and *** represent the 10\%, 5\%, and 1\% confidence levels. Specifications (1) and (2) use county means to replace missing values for independent variables. 
Table 6

Marginal Effects of Determinants of Type II Lending Authority

\begin{tabular}{|c|c|c|c|c|c|c|c|c|}
\hline & \multicolumn{2}{|c|}{ (1) } & \multicolumn{2}{|c|}{ (2) } & \multicolumn{2}{|c|}{ (3) } & \multicolumn{2}{|c|}{ (4) } \\
\hline & $\begin{array}{l}\text { Marginal } \\
\text { Effects }\end{array}$ & $\begin{array}{c}\text { Standard } \\
\text { Errors }\end{array}$ & $\begin{array}{c}\text { Marginal } \\
\text { Effects }\end{array}$ & $\begin{array}{c}\text { Standard } \\
\text { Errors }\end{array}$ & $\begin{array}{l}\text { Marginal } \\
\text { Effects }\end{array}$ & $\begin{array}{c}\text { Standard } \\
\text { Errors }\end{array}$ & $\begin{array}{l}\text { Marginal } \\
\text { Effects }\end{array}$ & $\begin{array}{c}\text { Standard } \\
\text { Errors }\end{array}$ \\
\hline EDU & 0.384 & 0.281 & 0.298 & 0.292 & 0.130 & 0.229 & 0.003 & 0.291 \\
\hline AGE & $0.090 * * *$ & 0.029 & $0.070 * *$ & 0.031 & $0.060 * *$ & 0.030 & $0.051 * *$ & 0.029 \\
\hline LNPERF & 0.295 & 0.291 & 0.219 & 0.299 & $0.559 * *$ & 0.216 & 0.264 & 0.237 \\
\hline FMNUM & 0.0002 & 0.000 & 0.00004 & 0.000 & $0.001 *$ & 0.000 & 0.001 & 0.000 \\
\hline COMP & 0.243 & 0.414 & -0.092 & 0.363 & -0.434 & 0.401 & -0.620 & 0.426 \\
\hline GOV & $-0.354 * * *$ & 0.118 & & & $-0.271 * * *$ & 0.099 & & \\
\hline LNRATE & -2.720 & 22.397 & -27.310 & 21.561 & 22.486 & 12.855 & 10.910 & 18.173 \\
\hline COST & 0.600 & 0.514 & 0.619 & 0.522 & -0.598 & 0.468 & $-1.040^{* * *}$ & 0.488 \\
\hline LLDRO & -0.157 & 0.165 & -0.257 & 0.163 & $-0.868^{* * *}$ & 0.196 & $-1.053^{* * *}$ & 0.248 \\
\hline CLDRO & $-1.158 * * *$ & 0.259 & $-1.147 * *$ & 0.489 & $-1.061 * *$ & 0.311 & $-1.255^{*}$ & 0.534 \\
\hline FMTYPE & 0.108 & 0.241 & 0.242 & 0.237 & 0.092 & 0.220 & 0.348 & 0.248 \\
\hline IOPERC & 0.039 & 0.046 & 0.047 & 0.046 & $0.096^{*}$ & 0.040 & $0.135^{* *}$ & 0.051 \\
\hline LIQ & 0.051 & 0.069 & 0.027 & 0.069 & $0.100 *$ & 0.073 & 0.089 & 0.064 \\
\hline PESHARE & -0.032 & 0.319 & 0.020 & 0.323 & -0.321 & 0.266 & -0.205 & 0.297 \\
\hline BANK (0=RCCs; $1=\mathrm{ABC})$ & -0.388 & 0.363 & $-0.580^{*}$ & 0.278 & 0.203 & 0.222 & 0.204 & 0.279 \\
\hline PROV (0=Zhejiang; $1=$ Jiangsu) & 0.295 & 0.192 & 0.140 & 0.181 & $0.583^{* * *}$ & 0.187 & $0.499 * *$ & 0.202 \\
\hline Observations & 80 & & 80 & & 61 & & 61 & \\
\hline
\end{tabular}

Notes: The dependent variable is decentralization of Type II lending authority, defined as follows: $0=$ full centralization, $1=$ partial or full decentralization. Marginal effects based on ordered probit estimates evaluated at sample means. Numbers in parentheses are standard errors. *, **, and *** represent the $10 \%, 5 \%$, and $1 \%$ confidence levels. Specifications (1) and (2) use county means to replace missing values for independent variables. 
Table 7

Marginal Effects of Determinants of Propensity to Seize Collateral Once a Loan Is Overdue

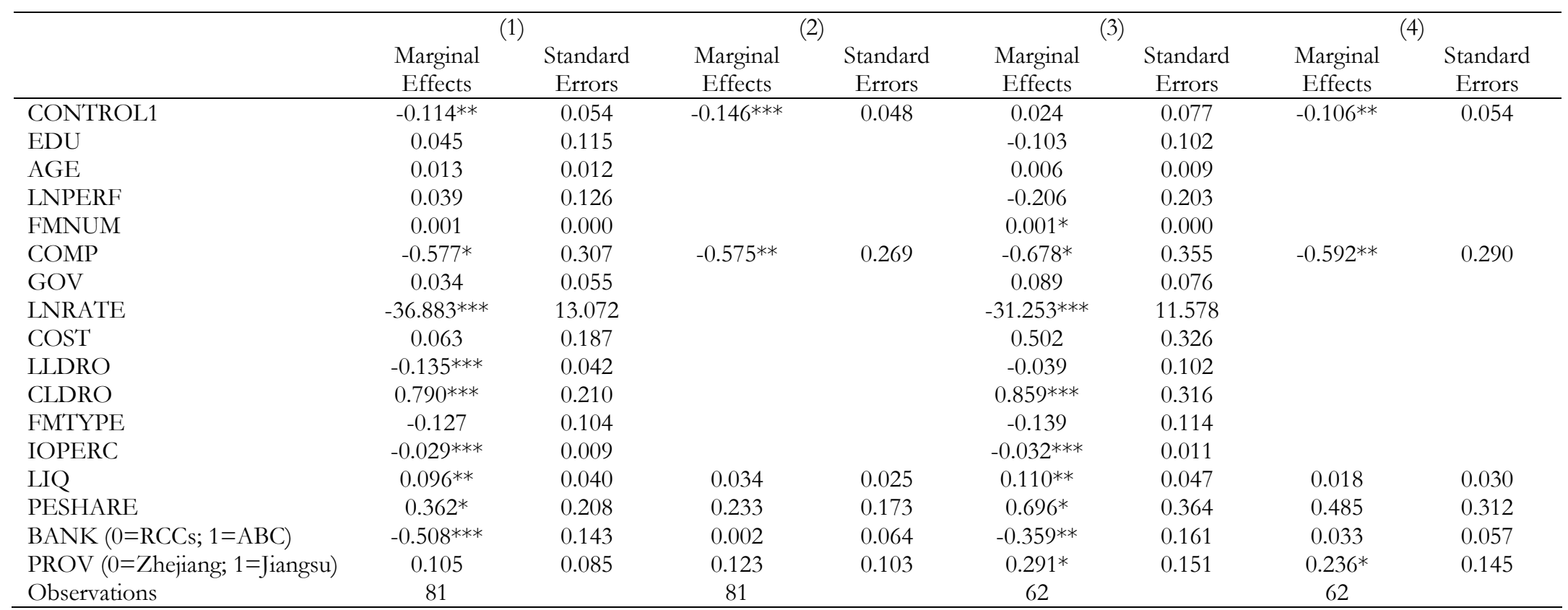

Notes: The dependent variable is the likelihood of seizing collateral if a loan is overdue, defined as follows: $1=$ definitely not, $2=$ unlikely, $3=$ possible, $4=$ likely, $5=$ yes, for sure. Marginal effects are for the probability of choice 5, seizing collateral for sure, based on ordered probit estimates evaluated at sample means. Numbers in parentheses are standard errors. *, **, and $* * *$ represent the $10 \%, 5 \%$, and $1 \%$ confidence levels. Specifications (1) and (2) use county means to replace missing values for independent variables. 